\begin{tabular}{|l|l|l||}
\hline \multicolumn{2}{|c|}{ PublisherInfo } \\
\hline \hline PublisherName & $:$ & BioMed Central \\
\hline \hline PublisherLocation & $:$ & London \\
\hline \hline PublisherImprintName & $:$ & BioMed Central \\
\hline \hline
\end{tabular}

\title{
2002 National Academy Fellows
}

\begin{tabular}{|l|l|l||}
\hline \multicolumn{2}{|c||}{ ArticleInfo } \\
\hline \hline ArticleID & $:$ & 4466 \\
\hline \hline ArticleDOI & $:$ & $10.1186 /$ gb-spotlight-20020502-01 \\
\hline \hline ArticleCitationID & $:$ & spotlight-20020502-01 \\
\hline \hline ArticleSequenceNumber & $:$ & 132 \\
\hline \hline ArticleCategory & $:$ & Research news \\
\hline ArticleFirstPage & $:$ & 1 \\
\hline \hline ArticleLastPage & $:$ & 3 \\
\hline \hline & & RegistrationDate : 2002-5-2 \\
ArticleHistory & $:$ & OnlineDate \\
\hline \hline ArticleCopyright & $:$ & BioMed Central Ltd2002-5-2 \\
\hline \hline ArticleGrants & $:$ & \\
\hline \hline ArticleContext & $:$ & 130593311 \\
\hline \hline
\end{tabular}




\section{David Bruce}

Email: davidb@biomedcentral.com

The US National Academy of Sciences yesterday announced the election of 72 new members and 15 foreign associates, in a list that includes both rising stars and venerable researchers.

Vernon Ingram at the Biochemistry Department, Massachusetts Institute of Technology - sometimes referred to as the 'The Father of Molecular Medicine' for his seminal work in identifying the single amino acid mutation that causes sickle cell anemia - is elected, 53 years after receiving his $\mathrm{PhD}$ and 32 years after his election to the Royal Society in London. In contrast, Yale University's Jennifer Doudna, has been elected to the Academy in recognition of her work in elucidating the structure and function of ribozymes and RNA-protein complexes only 13 years on from becoming a $\mathrm{PhD}$.

Also elected is Pat Brown from the Department of Biochemistry, Stanford University School of Medicine. It was his team that developed the microarray technology that has enabled meaningful analysis of the vast amounts of information generated by the numerous genome projects. In addition he is a committed proponent of freedom of access to academic research through his involvement with the Public Library of Science (PLoS).

Among the list of new foreign associates is Tomoko Ohta at the National Institute of Genetics, Japan. She has spent most of her post-doctoral career at the Institute developing the neutral theory of evolution in conjunction with Motoo Kimuri.

The seemingly ubiquitous Craig Venter is also elected this year, just as he leaves Celera, where he drove through the commercial sequencing of primarily his own genome, to rejoin The Institute for Genomic Research.

\section{References}

1. The National Academies, [http://www.nationalacademies.org/]

2. $72 \mathrm{New}$ Members Chosen by Academy, [http://www4.nationalacademies.org/news.nsf/isbn/ 043002?OpenDocument]

3. Vernam Ingram - Biochemistry Department, MIT, [http://web.mit.edu/biology/www/facultyareas/ facresearch/ingram.shtml] 
4. The Royal Society, [http://www.royalsoc.ac.uk/royalsoc/index.html]

5. Jennifer Doudna, [http://www.csb.yale.edu/people/doudna/jad/jad.html]

6. Pat Brown, [http://brownlab.stanford.edu/]

7. Public Library of Science, [http://www.publiclibraryofscience.org/]

8. National Institute of Genetics, [http://www.nig.ac.jp/home.html]

9. Celera, [http://www.celera.com/]

10. The Institute for Genomic Research, [http://www.tigr.org/] 